\title{
The Most Common Birds of the Somme Area
}

\author{
By DONALD and RONALD HOOPER, Somme, Sask.
}

Since October 1st, 1953 we have kept a record of every bird we have identified, on sheets of squared paper. From them one can easily figure out the species most commonly seen. Following are the ten commonest species in the Somme district from Oct. 1, 1953 to Sept. 30, 1954. The number after each species is the number of days that species was seen during the year.

1. English Sparrow - 248

2. Black-capped Chickadee - 213

3. Raven - 181

4. Hairy Woodpecker - 148

5. Robin - 144
6. Sharp-tailed Grouse - 125

7. Song Sparrow - 119

8. Barn Swallow - 118

9. Vesper Sparrow - 111

10. Killdeer - 108

If one made his observations in the close vicinity of a lake or river, the Mallard Duck would probably be among the ten commonest species.

Following are the three most common species for each month:

October, 1953 - English Sparrow, 27; Slate Colored Junco, 24; Magpie, 22. Total 53 species. Grand total including other Octobers, 80 species. Best day, Oct. 19, 27 species. (Best day for Oct., 1954, 32 species.

November - English Sparrow, 28; Magpie, 18; Chickadee, 16. Total 34 species. Grand total, 42 species. Best day, Nov. 10, 18 species.

December - Chickadee, 27; Raven, 25; Hairy Woodpecker, 25. Total 29 species. Grand total 33 species. Best day, Dec. 4, 15 species.

January, 1954 - Raven, 25; Hairy Woodpecker, 22; Brown-headed Chicadees 15. Total 22 species. Grand total 28 species. Best day, Jan. 13, 13 species.

February - Black-capped Chickadee, 26; Raven, 24; Brown-headed Chickadee, 15. Total 22 species. Grand total 25 species. Best day, Feb. 1, 12 species.

March - Black-capped Chickadee, 31; Hairy Woodpecker, 26; Canada Jay, 25. Total 27 species. Grand total 30 species. Best day, Mar. 8. 15 species.

April - Black-capped Chickadee, 27; English Sparrow, 22; Horned Lark, 22. Total 53 species. Grand total, 68 species. Best day, April 27, 27 species.

May - English Sparrow, 31; Mallard, 30; Robin, 30. Total 113 species. Grand total 137 species. Best day, May 31, 60 species.

June - Song Sparrow, 30; Robin, 30; Clay-colored Sparrow, 29. Total 95 species. Grand total, 111 species. Best day, June 8, 53 species.

July - Barn Swallow, 31; English Sparrow, 29; House Wren, 27. Total, 72 species. Grand total, 96 species. Best day, July 29, 41 species.

August - English Sparrow, 31; Barn Swallow, 27; Goldfinch, 24. Total, 88 species. Grand total, 98 species. Best day, Aug. 5, 32 species.

September - English Sparrow, 27; Robin, 22; Goldfinch, 20. Total, 66 species. Grand total, 104 species. Best day, Sept. 14, 25 species.

It is encouraging to notice that with the exception of the English Sparrow, the ten most common species are among the most beneficial and interesting of our birds. It is true that the Raven is a rascal at times, but I am sure that he more than makes this up with mice, insects and carrion that he eats. 